\title{
The Problem of the Omission of Word-final -s as Evidenced in Latin Inscriptions
}

\author{
Béla Adamik \\ (Hungarian Academy of Sciences, Budapest)
}

\begin{abstract}
Related to Herman (2000) and Herman (1987=2006), the present study deals with the problem of the deletion of word-final -s as evidenced in Latin inscriptions of the Empire. By reconsidering all items of the omission of -s recorded to date in the Computerized Historical Linguistic Database of Latin Inscriptions of the Imperial Age, the morphosyntactic explanation proposed by Herman $(1987=2006)$ as for relevant omissions will be replaced by a phonetic and phonosyntactic approach which evidences the all-time prevalence of the consonantal environment in the omission of word final-s. Accordingly, the phonosyntactically determined deletion of word final -s before a subsequent consonant existed continuously but to various degrees from the Old Latin age onward all along the history of Latin. This situation might have been inherited by the Romance languages, where different and complex morphological innovations led either to the discontinuation of the phenomenon of phonosyntactically determined deletion and the stabilization of word final -s (as in Western Romance), or to the completion of the deletion process and the complete loss of word final -s (as in Eastern Romance).
\end{abstract}

\section{Keywords}

inscriptions; phonology; word-final consonants; Old Latin; Vulgar Latin; Western and Eastern Romance

The present paper was prepared within the framework of the project NKFIH (National Research, Development and Innovation Office, former OTKA Hungarian Scientific Research Fund) No. K 108399 entitled "Computerized Historical Linguistic Database of Latin Inscriptions of the Imperial Age" (see: http://lldb. elte.hu/) and of the project entitled "Lendület ('Momentum') Research Group for Computational Latin Dialectology" (Research Institute for Linguistics of the Hungarian Academy of Sciences). I wish to express my gratitude to Zsuzsanna Sarkadi for her help in the revision of the English text. 
1. For introduction, let us cite the following passage from Herman (2000: pp. 40-41):

"Word-final [s] and [t] also show signs of weakening. In the oldest inscriptions, the loss of the word-final letter $s$ was quite common; yet spellings with the $-s$ become the general rule later. Presumably this was because the $s$ was indeed pronounced there, since most of Romance kept the Latin final [s]. Thus Spanish hijos < Latin filios (sons), quieres < quaeris (you seek), dos < duos (two), etc. It was the same in Old French, and indeed it still is in Modern French spelling, although in speech the language only preserves the sibilant in liaison, where it is voiced, such as the $[\mathrm{z}]$ that occurs at the end of the first word in the phrase grands hommes. Rumania and most of Italy lost the [-s], but this happened comparatively late, perhaps in the second half of the first millennium A.D. The details of this process are still not clear. A quotation from Cicero $($ Orator, 161$)$ is often adduced to show that at his time it was correct to pronounce word-final $/ \mathrm{s} /$, even in cases where older authors had felt it possible to omit it. If we take into consideration the usage of the Pompeii graffiti of A.D. 79, then we can deduce that final [s] was regularly present in their speech; and the later omission of the letter $-s$ from inscriptions of a Vulgar Latin character is very much less frequent than is the omission of $-m$. It is only from the fifth and sixth centuries onward that the number of epigraphic examples of omission of $-s$ grows appreciably, particularly in the Christian inscriptions from Rome and other parts of Italy; this period probably saw the origin of the future differentiation within Romania concerning the development of this feature."1

2. József Herman dealt with the issue in question not only in broad terms in his famous Vulgar Latin published in 2000, but he devoted a separate study (Herman 1987=2006) specifically to the problem of the omission of word final $-s$ in imperial inscriptions. In his study Herman concluded that the relevant omissions found in the Latin inscriptions of the Empire should be explained by morphosyntactic changes rather than by purely phonetic developments. He (Herman 1987=2006: pp. 35 and 37) argued that the frequency of such omissions is much lower than expected based on cases where a phonetic development lies behind a misspelling, e.g. in the case of the merger of $b$ and $v{ }^{2}$ or the loss of word final $-m$, the latter claim formulated also in his Vulgar Latin (see above). Herman (1987=2006: p. 36) also drew attention to the high frequency of omissions in the nominative of -us nouns and names in African curse tablets from Hadrumetum (from the $2^{\text {nd }}$ and/or $3^{\text {rd }}$ century A.D.), where $-u$ nominatives (after the omission of $-s$ ) seem to have become interchangeable with $-u$ accusatives (after the omission of $-m$ ) (e.g. Latrone,

1 As for the characteristic geographical division in Romance between the two opposite outcomes, i.e. eastern loss and western retention of the Latin word final $-s$, we see the two illustrative examples taken from REW n. 8883 "trēs 'drei'. Rum. trei, vegl. tra, it. tre, log. tres, engad. trais, friaul. tre, frz. trois, prov., kat., sp., pg. tres.” and REW n. 5960 "nōs 'wir'. Rum. nǒ̆, vegl., it. noi, log. nos, engad. nus, friaul. nus, frz. nous, prov., kat., sp., pg. nos.”. The borderline between Western and Eastern Romance languages in this respect and in many others lies along the so called Massa-Senigallia (former La Spezia Rimini) line as displayed in the map 'Tav. VII: Il dominio italo-romanzo' of Renzi \& Salvi (1985).

2 Revealed by the confusions of the letters B and V, such as INCOMPARAVILI for incomparabili, LLDB42247. 
Vagulu cadant < Latro, Vagulus cadant $\sim$ Latronem Vagulum cadant). To this interesting group of African curse texts we get back in detail later on.

The morphosyntactic explanation of Herman (1987=2006: p. 41) placed this phenomenon at the beginning of the development which, starting by this functional extension of the accusative to the nominative, might have led to the accusative becoming the base form or default case of nouns in African Latin (contrary to the situation of GalloRomance, which retained the nominative $-s$ ). Herman's explanation was received favourably by Adams (2013: p. 143) as follows: "There may be something in this idea".

Present study intends to reconsider Herman's morphosyntactic explanation in the light of inscriptional data of all regions of the so called Latin part of the Roman Empire including Africa, since Herman suggested that the (linguistically relevant) omissions of the word final $-s$ in inscriptions recorded from other regions of the Empire may be explained by the same morphosyntactic oscillation as in the case of the African curse tablets from Hadrumetum.

Such an investigation, expanded to the entire Latin part of the Empire, is the more reasonable because according to our preliminary investigation, relevant items with the omission of the word final $-s$ after $-u$ recorded from regions other than Latin Africa are hard to be explained by morphosyntactic factors, or at least by a functional extension of the accusative to the nominative. This is because in the relevant inscriptions confusions between the nominative and the accusative ${ }^{3}$ are extremely rare compared to the massive attestation of confusions between the accusative and the ablative. ${ }^{4}$

This situation compels us to reconsider all items of the omission of $-s$, especially those after a $-u$, recorded to date in the LLDB Database, and analyse them not only according to their territorial and chronological distribution, but also their phonetic context, and reintroduce the phonetic and/or phonosyntactic approach alongside or instead of the morphosyntactic one.

3. In the present analysis we included the entire so called Latin part of the Roman Empire and this way we were able to analyse relevant material of more than 40 provinces of the Empire entered to date in the Database. ${ }^{5}$ In order to see the changes over time, we divided the relevant material in two periods: an early one from the $1^{\text {st }}$ through the $3^{\text {rd }}$ century, and a later one from the $4^{\text {th }}$ through the $7^{\text {th }}$ century. ${ }^{6}$ The charts in Table 1 display the relative frequency, i.e. the distributional structure of all faults of purely

3 E.g. LLDB-43687: HIC REQVI|ISCIT ALBINVM EPISCOPVM = hic requiescit Albinus episcopus or LLDB46856: P SIGERIVS $=$ per Sigerium .

4 E.g. LLDB-8547: PER VALERIO = per Valerium or LLDB-1235: EX VOTVM = ex voto.

5 The data forms referred to in this survey numerically are used according to the state of the Database on 15/06/2017. They can be retrieved with the Extended Search module of the LLDB-Database (http://lldb. elte.hu/admin/search_2.php) with the settings and restrictions outlined in the next footnotes.

6 Accordingly, we have excluded data forms without a datation or with a date unclassifiable as for the current periodization with a break at 300 A.D., e.g. those dated with a time span of $201-400$, i.e. to the $3^{\text {rd }}-4^{\text {th }}$ centuries. 
phonological nature as for the consonantal subsystem, ${ }^{7}$ but only in a restricted selectivity focusing on those phenomena which are relevant to the current problem. These include the omission of word final $-s$ and word final $-m$, and the confusion between B and V (evidencing the merger of $b$ and $w) .{ }^{8}$ Herman used these phenomena in his comparison, so it is just appropriate that we use the same to check on his results. Other consonantal faults irrelevant to the current investigation are merged into the cumulative category labelled as 'Other'.

\section{Table 1: Relative frequency of consonantal faults according to LLDB}

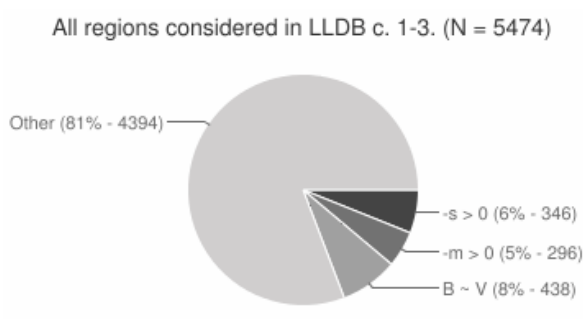

a) Early Empire
All regions considered in LLDB c. 4-7 ( $\mathrm{N}=4069)$

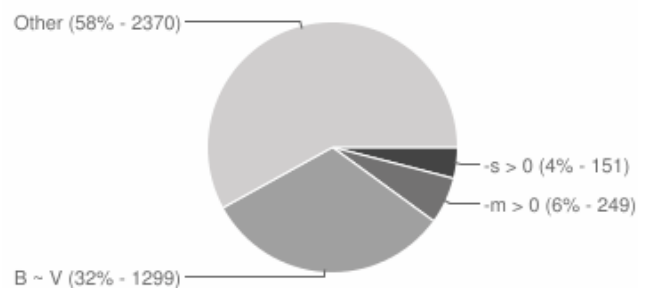

b) Later Empire

As we have seen, Herman (1987=2006: pp. 35 and 37) argued that the frequency of the omission of word final $-s$ is much lower than expected based on cases where a phonetic development lies behind a misspelling, e.g. in the case of the merger of $b$ and $w$, or the loss of word final $-m$. As for the former, i.e. the $\mathrm{B} / \mathrm{V}$ confusion, this assumption can be verified especially as for the later period, where the rates for this confusion revealing the merger of $b$ and $w$ are clearly much higher than those for the omission of final $-s$ (see Table 1, chart b): $32 \%(\mathrm{~B} \sim \mathrm{V})$ vs. $4 \%(-\mathrm{s}>0)$, while in the early period the $\mathrm{B} / \mathrm{V}$ confusion

7 In this investigation we excluded data forms with any morpho-syntactic alternative code (chosen from the lists labelled as 'Nominalia' or 'Verbalia' or 'Syntactica etc.' in the Database). We have also excluded data forms with a parallel alternative code chosen from the list labelled as 'Vocalismus' and purely orthographic phenomena as well (i.e. the codes $\mathrm{x}>\mathrm{SX} / \mathrm{CS} / \mathrm{XS} / \mathrm{XSS} / \mathrm{XX}$, qu $>\mathrm{CV}, \mathrm{i}(=[\mathrm{j}:] /[\mathrm{j}])>\mathrm{II}, \mathrm{c}>$ $\mathrm{K}, \mathrm{k}>\mathrm{C}, \mathrm{g}>\mathrm{C}$ and all codes referring to the problem of $\mathrm{H}$, i.e. $\mathrm{H}>0$, aspiratio vitiosa, $\mathrm{ch}>\mathrm{C}, \mathrm{ph}>\mathrm{P}, \mathrm{th}$ $>\mathrm{T}, \mathrm{ch}>\mathrm{H}, \mathrm{h}>\mathrm{CH}$, since the phoneme $h$ has already disappeared from the phonological subsystem of Latin by the end of the republican age). Finally we have also excluded data forms that may optionally be regarded as correct and therefore labelled as fortasse recte in the Database.

8 Thus we exclude from the phonological analysis cases such as FILIVS COMITI for filius comitis (LLDB14237) or OB PIETATE for ob pietatem (LLDB-7380) which can be interpreted not only phonologically, by the omission of final $-s$ (coded as $-\mathrm{s}>\varnothing$ ) or of final $-m$ (coded as $-\mathrm{m}>\varnothing)$, but also morphosyntactically, by the confusion of the dative and genitive (coded as dat. pro gen.), or the ablative and accusative cases (coded as abl. pro acc.), and therefore included in the morphosyntactical analysis. As a result, we included only phenomena which are purely phonological in nature, such as CVIV IN for cuius in (LLDB-27346 coded by $-\mathrm{s}>\varnothing$ ) or ANNORV for annorum (LLDB-39689 coded by -m > $\varnothing$ ), where a parallel morphosyntactic explanation is not possible at all, just like those losses of word final -s evidenced metrically in verse inscriptions (as CVIVS SINT = cuiu' sint in a hexameter coded by elisio -s LLDB-35308). Of course, we included into the purely phonological category the items of omission of the final $-s$ in the nominative of -us nouns and names such as IVLIANV VET for Iulianus veteranus (LLDB-14892 coded only by $-\mathrm{s}>\emptyset$ ) which otherwise should have been coded alternatively by the morphosyntactic code acc. pro nom. in our database considering Herman's explanation. 
of $8 \%$ only slightly exceeds the rate of omission of final $-s$ of $6 \%$ (see Table 1 , chart a). At the same time, as for the omission of word final $-m$, this assumption is hardly supported by the findings of our database, since the rates of both omissions are similar: ${ }^{9}$ on average in the early period the $-\mathrm{s}>0$ with $6 \%$ only slightly exceeds the $5 \%$ rate of $-\mathrm{m}>0$ (see Table 1, chart a), and in the later period the $-\mathrm{m}>0$ with $6 \%$ only slightly exceeds the $4 \%$ rate of $-\mathrm{s}>0$ (see Table 1 , chart $\mathrm{b}$ ). In short, if the rates of omissions of final consonants $-s$ and $-m$ are similar, the phonetic explanation considered evident as for the loss of final $-m$ cannot be excluded automatically as for the loss of final $-s$ either.

This reopens the way for a phonetic explanation, which is made even more probable if we consider the incidents of case confusions between accusative and nominative displayed in the charts of Table $2 .^{10}$

9 According to Herman (1987=2006: p. 35), the incidence of the loss of final $-m$ is fifteen or twenty times higher than that of final $-s$ : this exaggerated difference can be explained by the fact that Herman (as in note 3 p. 34) took his contrastive data among others from Väänänen (1966): "A Pompéi, Väänänen (1966, 80) a relevé 23 exemples de »s final omis sans raison apparente«, qui s'opposent à environ 170 cas de » $m$ omis sans raison apparente (ibid. 73-75)". However, a considerable part of Väänänen's examples under the label '- $m$ omis sans raison apparente' consists of either "Accusatifs en - $a(m)$ ” like Succesus amat ancilla $(m)$ and ad porta $(m)$ Romana $(m)$ or "Accusatifs en $-e(m)$ " such as $q u(a) e$ amas Felicione $(m)$ and ante aede $(m)$, which can all be interpreted also as examples of confusing cases (the former two would be coded alternatively by Nom./Abl. pro Acc., the latter two by Abl. pro Acc. in our Database), and therefore they are to be excluded from a purely phonetic analysis. Here the potential influence of morphosyntactic changes cannot be left out of consideration, since in Vulgar Latin the merger of the accusative and ablative cases was a general process affecting all declensions both in the singular and in the plural, occurring in prepositional phrases as well as without prepositions, also appearing in the ablative absolute clause, cf. the following examples: LLDB-59514: NATVS | CASAS MAIORES = natus Casis Maioribus (acc. pro abl.), LLDB-42799: AB CONSERVAS | PEDISEQVAS = a conservis pedisequis (acc. pro abl.), LLDB-10836: OB MERITIS = ob merita (dat./abl. pro acc.), LLDB-6152: ADIVTANTIBVS NEPO|TES SVOS FILIES FILIOS GREGOR|IO ET LAVRENTIO FRATRES = adiutantibus nepotibus suis, filiae filiis, Gregorio et Laurentio fratribus (ablativus absolutus accusativis permixtus) etc. Accordingly, LLDB-44030: ARA POSVIT $=$ aram posuit (nom./abl. pro acc. $/ \mathrm{-m}>\varnothing$ ) and LLDB-17619: TITVLO PO|S = titulum posuit (dat./abl. pro acc. / -um > O) or LLDB-35448: EXTRA | MACERIA = extra maceriam (nom./abl. pro acc. / -m > $\varnothing)$ and LLDB-50658: [E]XTRA FVNDO = extra fundum (dat./abl. pro acc. / -um > O) all have a complex, morphosyntactic and phonological explanation, thus Väänänen's examples mentioned above cannot be explained exclusively phonetically by dropping the $-m$. The same is true for LLDB-44959: OB HONORE $=o b$ honorem $($ abl. pro acc. $/-\mathrm{m}>\varnothing$ ) because of LLDB-58148: OB HO|NORIBVS = ob honores (dat./abl. pro acc.) and (inverse) LDB-41852: CVM | QVAM = cum qua (acc. pro abl. / - $>$-m) because of LLDB-48790: C|]VM QVEM = cum quo (acc. pro abl.). As for the confusion of the cases, see Adamik (2014b).

10 The chart a) for the Early Empire contains 28 items of Nom. Acc. (= 13 nom. pro acc. +15 acc. pro nom.) and 470 items of Acc. $\sim$ Abl. (= 169 acc. pro abl. +70 nom./acc. pro abl. +102 dat. $/$ abl. pro acc. + 129 abl. pro acc.). The chart b) for the Later Empire contains 18 items of Nom. $\sim$ Acc. (= 8 nom. pro acc. +10 acc. pro nom.) and 523 items of Acc. $\sim$ Abl. (= 190 acc. pro abl. +87 nom./acc. pro abl. + 116 dat./ abl. pro acc. +130 abl. pro acc.). Other case confusions (e.g. dat. pro gen., gen. pro dat. etc.) irrelevant to our current investigation are merged into the cumulative category labelled as 'Other'. 


\section{Table 2: Relative frequency of case confusions according to LLDB}

All regions considered in LLDB c. 1-3 AD $(N=1623)$

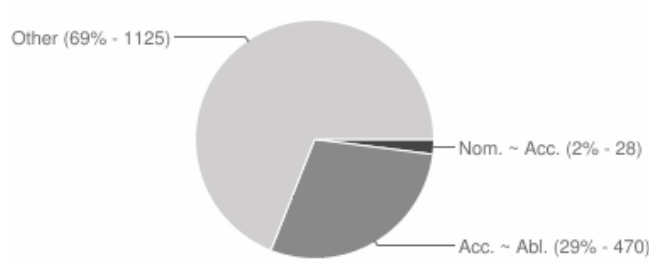

a) Early Empire
All regions considered c. 4-7 $\mathrm{AD}(\mathrm{N}=976)$

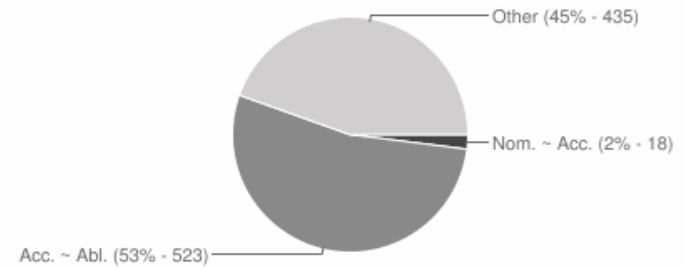

b) Later Empire

This phenomenon was fundamental in Herman's reasoning, who explained the $-u$ nominatives (after the omission of $-s$ ) found on African curse tablets by a functional extension of the $-u$ accusatives (after the omission of $-m$ ) to the nominative (cf. Latrone, Vagulu cadant < Latro, Vagulus cadant $\sim$ *Latronem Vagulum cadant). However, this morphosyntactic explanation otherwise reasonable for the African curse tablets from Hadrumetum fails not only with respect to the other types of epigraphic sources (i.e. stone inscriptions etc.) in Africa, but also to all types of inscriptions of other regions of the Empire, including curse tablets. This is because, according to our own relevant findings, the rates for confusion between nominative and accusative are everywhere very low, not only in relation to every type of case confusions, but especially in contrast to the confusion between accusative and ablative cases (see the charts in Table 2). While the average rate of the former is $2 \%$ in both periods, that of the latter is $29 \%$ in the early period, increasing to $53 \%$ in the later period, which proves the increasing productivity of the latter and the stagnant unproductivity of the former.

4. Consequently, those quite isolated occurrences of accusative instead of nominative in the relevant African curse texts should rather be explained differently. The most probable alternative explanation involves the phenomenon of the so called accusative used in lists, proposed by Herman (1987=2006: p. 39), at that time a less probable alternative explanation, later made more than probable by Adams. As Adams (2013: p. 250) pointed out, the texts of the relevant curse tablets from Hadrumetum - with long lists of names of racehorses or drivers cursed by a verb such as cadat or cadant, expressing a wish that they fall (often written mechanically and this way contradicting the agreement in number, sometimes with a plural subject and singular verb such as Ganimede Cursore cadat or singular subject and plural verb like Delusore cadant) - have a special restricted syntax, which resembles that of another text type containing similar lists: the recipes of Apicius, where lists of ingredients for a recipe may be in either the nominative or the accusative. ${ }^{11}$

An illustrative example of these curse texts (from Africa, Hadrumetum, $2^{\text {nd }}-3^{\text {rd }} c$. A.D.) is cited by Audollent (1904: n. 275), edited later by Kropp (2008: n. 11.2.1/12)

11 Cf. Apicius 9, 10, 3: ius in sarda: ... mentam, cepam ... and 9, 10, 6: ius in mugile salso: ... cepa, menta ... cited by Adams (2013: p. 229). This phenomenon was called "Rezeptakkusativ" by Svennung (1935: p. 186), cf. Hoffmann \& Szantyr (1972²: pp. 29-31). 
and by EDCS, which restores all the relevant items as nominatives by always supplying the "missing" final $-s$ as in Vagulu(s), excluding all superfluous syllables as Latro\{ne\}. ${ }^{12}$ Herman, however, - as Adams (2013: p. 249) points out - was surely right to treat them as accusatives, because the same texts also have third declension names coordinated with those in $-u$, which bear unambiguous accusative forms with the omission of - $m$ : i.e. Latrone $(m)$ Vagulu(m) cadant and not Latro\{ne\} Vagulu(s) cadant.

We may add that the explanation offered by Adams seems to be the most fitting one. For this, it is enough to compare the different textual compositions of the central part of this curse tablet consisting of lists of cursed names and of inserted cursing verb forms (cadat / cadant), peripheral part of the same tablet (see the reproduction of the tablet by Audollent 1904: p. 381) containing the other version of the main curse but this time in syntactically well-formed sentences starting with Obligate et gravate equos ... et agitantes ... etc. ${ }^{13}$ Quite conspicuously, in this other part we find neither confusions of the accusative and nominative cases nor omissions of final $-s$. This proves that these are actually not examples of the omission of word final $-s$, but omissions of word final $-m$ (cf. Latrone $(m)$ $\operatorname{Vagulu}(m)$ cadant). We have only one clear nominative in the list of cursed names with the final -s: Eucles cada\{n\}t.

Finally, this explanation involving the phenomenon of the so called accusative of enumeration is strongly supported by the very low, $2 \%$ rate of the confusion between the nominative and accusative cases found on African inscriptions other than curse tablets in both periods, which stands in sharp contrast with the $35 \%$ and $63 \%$ rate of confusions between the accusative and the ablative case (see the charts in Table 3).

\section{Table 3: Relative frequency of case confusions in Africa according to LLDB}

Africa c. $1-3(\mathrm{~N}=128)$

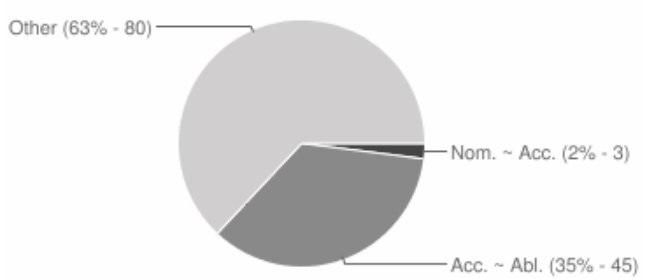

a) Early Empire

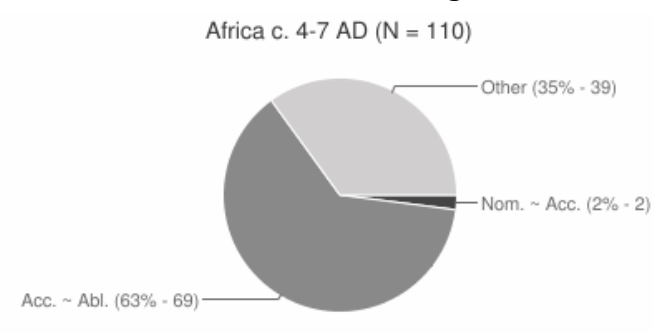

b) Later Empire

5. Let us now return to the phonological approach. As mentioned above, we are going to analyse all items of the omission of $-s$ with a purely phonetic background not only according to their chronological and/or territorial distribution, but also their phonetic contexts. This analysis can be realized thanks to our data collection standards, as we enter not only the words containing the faults but also the subsequent words. This way we

12 For the whole text see EDCS under EDCS-34000306.

13 In the EDCS edition the peripheral text is indicated after the double slash $(/ /)$. 
were able to establish three categories for our analysis of the phonetic context. ${ }^{14}$

1. Omissions occurring before a subsequent consonant (e.g. EIV MATO for eius Mato, LLDB-4518). ${ }^{15}$

2. Omissions occurring before a subsequent vowel (e.g. CVIV IN for cuius in, LLDB-27346).

3. Omissions where it was not possible to determine the subsequent phoneme; these are therefore left out of consideration in this present analysis of phonetic context. ${ }^{16}$

14 In our underlying analysis we also made a subdivision to show whether the omission occurred at the end of a line (in the Database indicated by a vertical bar |) or not. This subdivision was made just for the sake of accuracy considering the assumption (represented e.g. by Adams 2013: p. 33) that those omissions at the end of a line should rather be regarded as abbreviations enforced by the lack of space and therefore to be left out of consideration. However, the role of the end of a line and thus the concomitant effect of lack of space in the omission of a final consonant is clearly overemphasized in the relevant literature, which hardly acknowledges the existence of actual epigraphical practices for saving space in the field of inscription, such as 1) the use of various kinds of ligatures, a common practice in the Pre-Christian era (e.g. RIU 2, 540: Caecilius|, RIU 3, 879: Maximus| by different VS ligatures, both from the $3^{\text {rd }}$ century A.D.), which was indeed much less common in the Christian era (although see e.g. RIU 1, 78: VIVA by VA ligature or RIU 1, 82: PATRE by PA ligature, both Christian inscriptions from the $4^{\text {th }}$ century A.D.), 2) inserting minuscule or small letters between capital letters or within a capital letter (e.g. RIU 3, 681: Quartus| written by a small v between T and S, or RIU 1, 100: Primus | by engraving a small s within the V), or 3) carving extra text in the marginal mouldings, e.g. by engraving a final $-s$ out of the inscription field on the frames (e.g. from the $3^{\text {rd }}$ century A.D. RIU 3, 720: Avitianu $|s|$ and Secundu $|s|$, RIU 1, 182: veteranu $|s|, 1^{\text {st }-2^{\text {nd }}}$ century A.D.); as for these practices in general, see Edmondson (2015: pp. 125-126) and Proskauer (1910: pp. 51-52). Consequently, a final $-s$ could have been displayed also at the end of a line of an inscription despite the lack of space - had there been any intention to display it. Moreover, the relevant literature fails to consider those items where, standing at the end of the line, the $-s$ was omitted even though there would have been enough free space for engraving it (e.g. AE 1956, 51: Floru(s) || (LLDB-20482), CIL 13, 816: eiu(s) || (LLDB-21814), AIJ 29: Serenu(s) | (LLDB-2113), TitAq 1, 299: Fe $\mid$ stu(s) | (LLDB-19309) etc.; these cases are indicated by a space before the I in LLDB). Furthermore, the theory of the widely assumed pressure allegedly triggered by the lack of space at the end of a line cannot be confirmed by linguistic reasons. To prove just that, let us briefly consider the situation in Roman Sardinia, which has a very innovative consonantism (out of the 188 Sardinian consonantal data forms recorded to date in LLDB 123, i.e. $65 \%$ refers to the B/V confusion), while the material yields only sporadic examples of the omission of word final $-s$ (cf. Lupinu 2000: 65: e.g. ILSard 81: $\operatorname{diebu}(s) X V I I, 2^{\text {nd }}-3^{\text {rd }}$ century A.D., LLDB-64270 or ILSard 358: plu(s) minus, $6^{\text {th }}$ century A.D., LLDB-64273). While there is a vast number of examples of word final $-s$ written both at the end or in the middle of a line (in 158 inscriptions in EDCS dated to 1-300 A.D. there are ca. 90 items of final $-s$ written at the end of a line, while in 276 Christian inscriptions in EDCS of later periods there are ca. 80 items of final $-s$ written at the end of a line). How could it be possible that the alleged pressure of general scope triggered by the lack of space at the end of a line did not appear in Sardinia at all (except for one single item from the $2^{\text {nd }}-3^{\text {rd }}$ century A.D. Amarantu(s) | pater, CIL 10, 7973, LLDB-65061)? This supports the view that the above mentioned reservation is probably superfluous and should be ignored. In the relevant charts, all types of omissions of $-s$ before any consonant and before a vowel will be lumped together indicating their totalized numbers and again their rates in relation to each other; at the same time, the figures for each subcategory will be indicated in the footnotes belonging to the charts.

15 In this first group we introduced a distinction as to whether the omission occurred before a subsequent $s$ or not. We did so because in such cases we can take into account a kind of haplology, notwithstanding that the metrical cases of the omission of a final $-s$ such as CVIVS SINT as cuiu' sint (LLDB-35308, coded by elisio $-s$, further examples: GENVS [S]I = genu' si LLDB-29412, SITVS SVM = situ' sum LLDB-51840, LVTVS SI = lutu' si LLDB-55063, ZENONIS SVASIT = Zenoni' suasit LLDB-60455, DEDITAS SIBI = dedita' sibi LLDB-63623) in hexameter clearly prove that a final -s could have been lost in pronunciation before a subsequent $s$ - too, cf. with further argumentation Adamik (2014a: p. 154).

16 E.g. if the omission occurred at the end of the entire inscription (in LLDB indicated by a double vertical bar ||, e.g. EIV||, LLDB-21814) or before a fracture (in LLDB indicated by square bracket [, e.g. TRE [, 
The idea for such an analysis of the loss of word-final -s based on the phonetic context during the Imperial Age came from the fact that the same phenomenon occurred in Old Latin as well. In the Old Latin of the inscriptions from the $3^{\text {rd }}$ and $2^{\text {nd }}$ centuries B.C., we see that a final $-s$ was very often omitted before a consonant, but rarely before a vowel. This might reveal a restricted phonetic realization of the word final $-s$, depending on its phonetic environment. The word final $-s$ seems to have been pronounced before a vowel but not before a consonant, a phenomenon corroborated by early Latin verse (Plautus and Terence etc.), where the final $-s$ often does not make position after a short vowel and before a consonant while it does before a vowel, as Adams (2013: p. 132) formulates, with a nice example from Ennius, Ann. 377: nos sumu' Romani, qui fuimus ante Rudini. In the Old Latin inscriptions of the Republican age, the omission of the $-s$ was not at all confined to the position before a consonant (e.g. Populicio(s) M(arci) CIL 12 28 ), but occurred also before vowels (e.g. castu(s) amabili(s) CIL $\left.1^{2}, 1259\right)$, even if relatively seldom, see Table $4 .{ }^{17}$

The prevalence of the consonantal environment in the omission of word final $-s$ can be evidenced by comparing these proportions (i.e. $24=10 \%$ vs. $205=90 \%$ ) to the proportions where the word final $-s$ is not omitted in the same phonetic environment (i.e. $2119=24 \%$ vs. $6564=76 \%$ ), i.e. by the contrastive (14\%) difference between the loss $(90 \%)$ and retention $(76 \%)$ before subsequent consonants. ${ }^{18}$

\section{Table 4: Frequency of $-\mathrm{s}>0$ and $-\mathrm{s}=\mathrm{S}$ according to phonetic context in CIL 1}

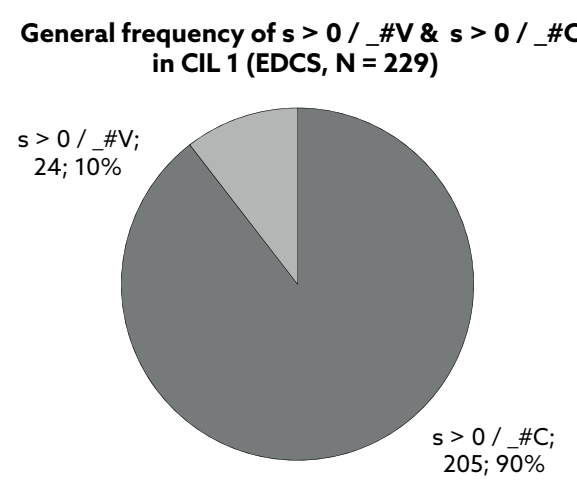

a) omission of $-\mathrm{s}$

\section{General frequency of $s=S / \_$\#V \& $s=S / \_C$ in CIL 1 (EDCS, 5296 inscriptions)}

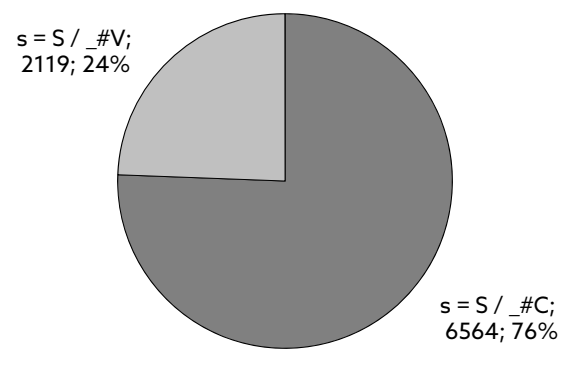

b) retention of $-\mathrm{s}$

LLDB-48079), or if there was no way to identify the Roman numeral subsequent to the omission, e.g. in MESE V[ (LLDB-32011) the V can be equated either with V = quinque or completed either as VI = sex, VII = septem, $\mathrm{VIII}=$ octo, or even $\mathrm{VIIII}=$ novem .

17 Cf. the examples in Wachter (1987: pp. 256, 343, 348, 356, 434). The facultative omission was not confined to $-s$, but extended also to final $-m$ and $-t$, cf. Wachter (1987: p. 356).

18 Since the Republican material is not considered in the LLDB Database at all, we analysed the relevant material of CIL $1^{2}$ in EDCS. Data for chart a) in Table 4: s >0/_\#C $205=1 . s>0 /$ _ \#C 156 + 2. s > 0 $/ \_\#|\mathrm{C} 32+3 . \mathrm{s}>0 / \ldots \# \mathrm{~S} 15+4 . \mathrm{s}>0 / \ldots \#| \mathrm{S} 2+5$. elisio -s /_\#S $0+6$. elisio -s /_\#C 0 ; s >0/_\#V 24 $=7 . \mathrm{s}>0 / \ldots \mathrm{V} 19+8 . \mathrm{s}>0 / \ldots$ _ $\mid \mathrm{V} 5$; excluded items with undeterminable phonetic environment: $18=$ 9. $\mathrm{s}>0 / \ldots \mathrm{hV} 0+10 . \mathrm{s}>0 / \ldots \#|\mathrm{hV} 0+11 .-\mathrm{s}>0 / \ldots \#| \mid 18(||$ here refers to cases where the omission occurred at the end of the entire inscription or before a fracture). 
This phenomenon found in Old Latin is of course well-known in the relevant literature and has been involved in investigations of the present problem of final $-s$ in Vulgar Latin since long ago, but with a negative conclusion: that thanks to the general restoration of $-s$ in all environments, both in writing and speech, within the framework of a standardisation movement in the late Republic, there is no connection between the Old Latin and the Vulgar Latin phenomena. As Adams (2013: p. 135) formulates: "Was there any continuity between usage in the earlier Republic, when $-s$ was often left out in inscriptions from Italy, and Romance, where it was lost in Italy? (...) The case can be made that there is only one conclusion fully justified by the evidence. Final $-s$ was restored right across the social spectrum and in all areas by the early Empire, and it was maintained for centuries. The loss that shows up in Italian and some other Romance languages must have occurred very late, and was not a direct continuation of the situation obtaining in the archaic period." 19

6. As mentioned above, I found a comparatively rich material for the omission of final $-s$ in the relevant epigraphic material of the Early and the Later Empire, which can be explained neither by extra-linguistic factors nor by morphosyntactic changes, only by phonetic developments. The next logical step was to analyse this data set based on the phonetic environment in which the omission occurred - led by the presupposition that the loss of final $-s$ might have been conditioned by the differing phonetic environment just as in Old Latin. In the following paragraphs, first we will analyse the problem on a more general level, pertaining to material from the entire Latin part of the Empire, then specifically for upper and lower Italy in our two periods, the Early and the Later Empire. In the analysis, the proportions of omission and retention of word final $-s$ will be compared before consonants and vowels. The results of our analysis are as follows.

\section{Table 5: Frequency of $-\mathrm{s}>0$ and $-\mathrm{s}=\mathrm{S}$ according to phonetic context in c. 1-3 AD}

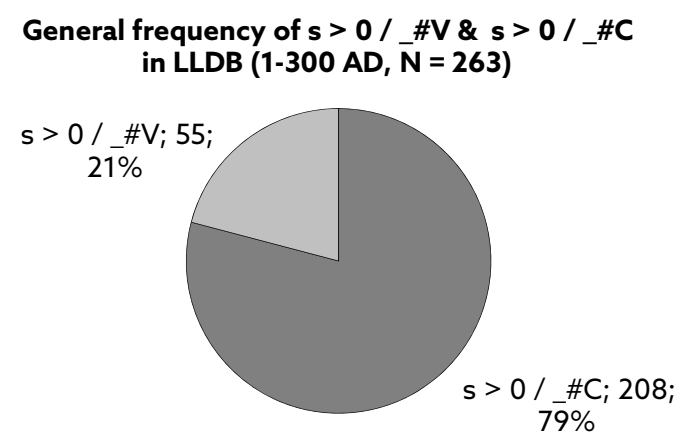

a) omission of $-s$

\section{General frequency of $s=s / \# V \& s=s / \# C$ in EDCS (1-300 AD: 18716 inscriptions)}

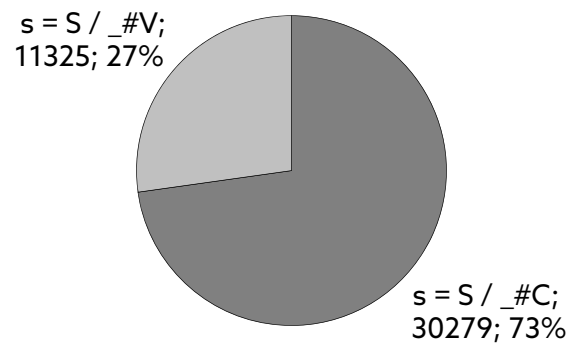

b) retention of $-\mathrm{s}$

19 Herman (2000: pp. 40-41) describes the situation in a similar way, but with a more cautious conclusion as for a potential connection between Vulgar Latin and Romance developments (see at the end of the citation above). 
As for the Early Empire, i.e. the period of the $1^{\text {st }}$ through $3^{\text {rd }}$ century, it can be stated that on the average $79 \%$ of all omissions of the final $-s$ occurred before a subsequent consonant and only $21 \%$ before a subsequent vowel, see chart a) in Table $5 .{ }^{20}$ If we count the rates for the occurrences when a word final $-s$ is written correctly in 18,716 dated inscriptions found in EDCS for the early period (i.e. 1-300 A.D.), and check whether they occur before a consonant or a vowel, we get the following results, see chart b) in Table $5.73 \%$ of the final $-s$ written correctly occurs before a subsequent consonant and $27 \%$ before a subsequent vowel.

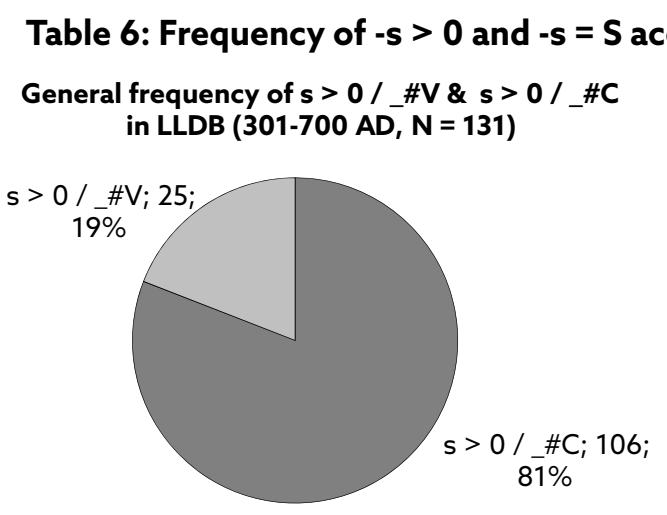

a) omission of -s

\section{General frequency of $s=S / \ldots V \& s=S / \# C$ in EDCS (301-700 AD: 2624 inscriptions)}

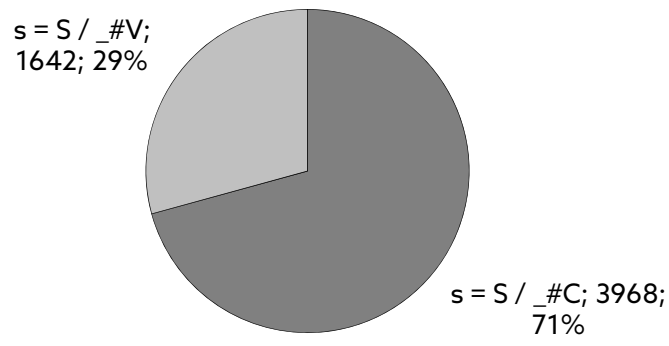

b) retention of $-\mathrm{s}$

During the Later Empire, i.e. the period from the $4^{\text {th }}$ through $7^{\text {th }}$ century, on average $81 \%$ of all omissions of the final $-s$ occurred before a consonant and only $19 \%$ before a subsequent vowel, see chart a) in Table $6 .{ }^{21}$ In the 2,624 dated inscriptions found in EDCS for the later period, $71 \%$ of the final $-s$ written correctly occurs before a subsequent consonant and $29 \%$ before a subsequent vowel, see chart b) in Table 6 .

Consequently, since the rates of omission of $-s(79 \%$ vs. $21 \%)$ and retention of $-s(73 \%$ vs. $27 \%)$ are quite close to each other in both phonetic environments during the Early Empire (by a low difference of $6 \%$, which is just too close to the error margin of around 4-5\%), we are not really entitled to assume that the omission of final $-s$ happened as conditioned by the phonetic environment. On the other hand, since during the later period the rates of both the omission of $-s(81 \%$ vs. $19 \%)$ and the retention of $-s(71 \%$ vs. $29 \%)$ are different by a significant $10 \%$ in both phonetic environments, we might more safely assume that the omission of the final $-s$ happened more and more

20 Data for chart a) in Table 5: s $>0 / \ldots$ C $208=1 . \mathrm{s}>0 / \ldots$ C $84+2 . \mathrm{s}>0 /$ _ $\mid \mathrm{C} 98+3 . \mathrm{s}>0 /$ \# $11+$

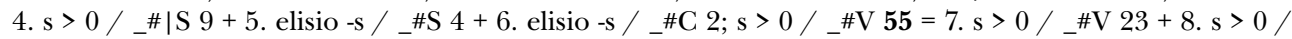
_\#|V 32; excluded items with undeterminable phonetic environment: $81=9 . \mathrm{s}>0 / \ldots$ hV $5+10$. s $>0 /$ _\#|hV $6+$ 11. -s $>0 /$ _ $\#|| 70$.

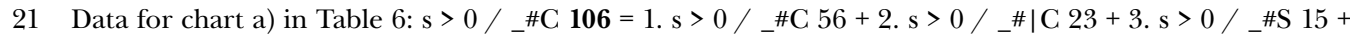

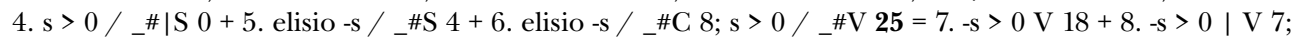
excluded items with undeterminable phonetic environment: $18=\overline{9}$. s $>0 / \ldots$ hV $2+10 . \mathrm{s}>0 / \ldots \# \mid \mathrm{hV} 0$ +11. $-\mathrm{s}>0 /$ _ \#|| 16 . 
as conditioned by the phonetic environment, i.e. more and more often before a subsequent consonant.

Accordingly, in the later period the position before a subsequent consonant seems to have gained a kind of relevance in the loss of the final $-s$ as deduced from the contrastive $(10 \%)$ difference between its loss $(81 \%)$ and retention $(71 \%)$ before subsequent consonants. As for the early period, the same conclusion can be drawn only with a caveat because of the less contrastive $(6 \%)$ difference between loss $(79 \%)$ and retention $(73 \%)$ before subsequent consonants. However, it is still remarkable that the rate of loss of $-s$ is always higher than the retention of $-s$ before subsequent consonants; the opposite has never been attested.

7. If we perform the same analysis on a more restricted material, this time on two regions, those most relevant as for the issue in question, i.e. on Northern Italy (Reg. VIII-XI) and Middle and Southern Italy (Reg. I-VII), we get the following results.

Table 7: Frequency of $-\mathrm{s}>0$ and $-\mathrm{s}=\mathrm{S}$ in phonetic context in Northern Italy c. 1-3 AD

Frequency of $s>0 / \ldots V \& s>0 /$ \#C in Northern Italy Frequency of $s=S /$ \#V \& $s=s /$ \#C in Northern Italy Reg. VIII-XI (LLDB, 1-300 AD, $N=24)$

Reg. VIII-XI (EDCS, 1252 inscr. of 1-300 AD)

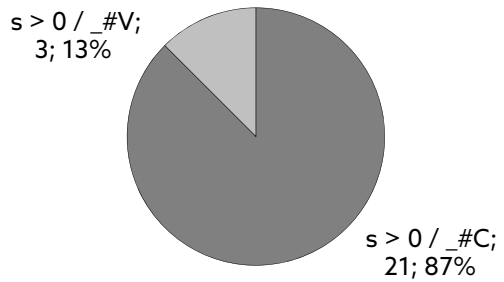

a) omission of -s

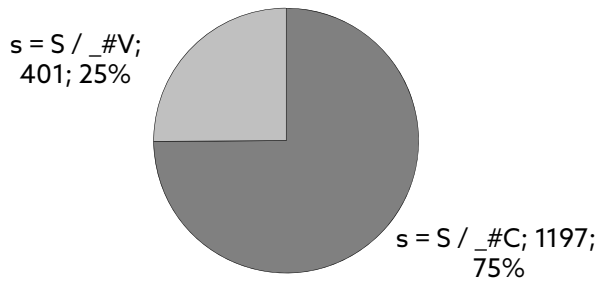

b) retention of -s

In the Northern Italy (Reg. VIII-XI) of the Early Empire, the rates of both the omission of the word final $-s(87 \%)$ and the retention of $-s(75 \%)$ compared by phonetic environment show a difference of a significant $12 \% .^{22}$

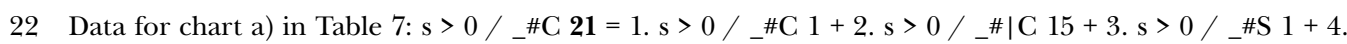

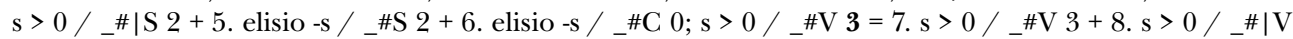
0 ; excluded items with undeterminable phonetic environment: $1=9 . \mathrm{s}>0 / \ldots \# \mathrm{hV} 1+10 . \mathrm{s}>0 / \ldots \# \mid \mathrm{hV} 0$ $+11 .-\mathrm{s}>0 /$ _ \# || 0 . 
Table 8: Frequency of $-\mathrm{s}>0$ and $-\mathrm{s}=\mathrm{S}$ in phonetic context in Southern Italy c. 1-3 AD

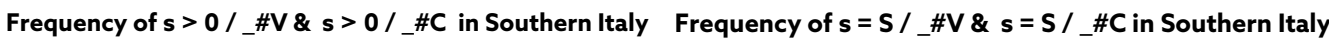
Reg. I-VII (LLDB, 1-300 AD, $N=22$ ) Reg. I-VII (EDCS, 3439 inscr. of 1-300 AD)

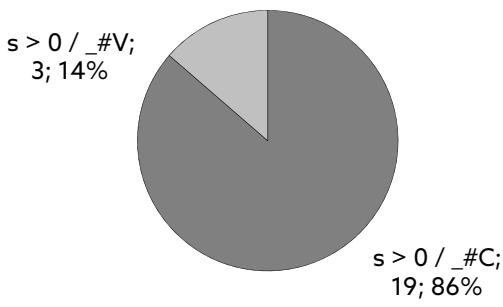

a) omission of -s

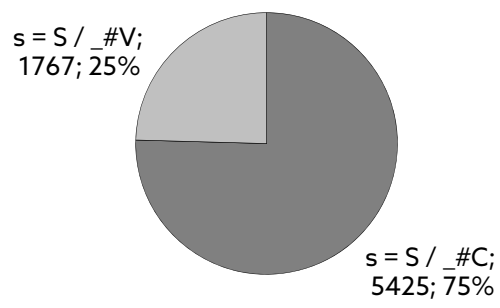

b) retention of $-s$

At the same time, the rates of both the omission of the final $-s(86 \%)$ and the retention of the final $-s(75 \%)$ compared by phonetic environment for Middle and Southern Italy (Reg. I-VII) of the Early Empire show a similar difference of a significant $11 \% .^{23}$ This means that the extent of difference is the double of the difference in the Early Empire in general $(6 \%)$ in both considered regions of Italy (in the former, doubled exactly with $12 \%$; in the latter, doubled only almost with $11 \%$, see Table 5 ).

If we consider Northern Italy (Reg. VIII-XI) and Middle and Southern Italy (Reg. I-VII) in the later Empire, the extent of difference increases further, see Tables 9-10.

Table 9: Frequency of $-\mathrm{s}>0$ and $-\mathrm{s}=\mathrm{S}$ in phonetic context, Northern Italy c. 4-7 AD

Frequency of $s>0 / \# \vee \& s>0 / \# C$ in Northern Italy Frequency of $s=s /$ \#V \& $s=s /$ \#C in Northern Italy Reg. VIII-XI (LLDB, 301-700 AD, N = 19) Reg. VIII-XI (EDCS, 1681 christ. inscr. of ca. 301-700 AD)

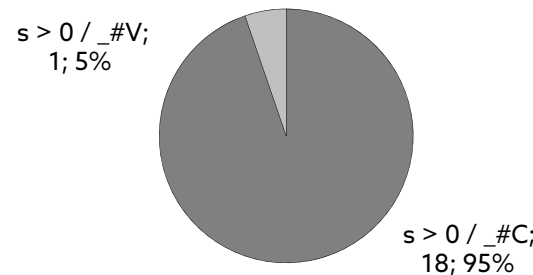

a) omission of -s

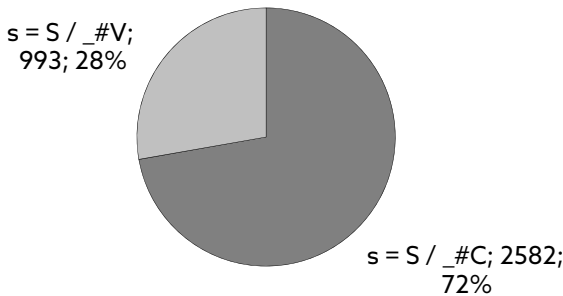

b) retention of -s

In the Northern Italy (Reg. VIII-XI) of the Later Empire, the rates of both the omission of the word final $-s(95 \%)$ and the retention of $-s(72 \%)$ compared by phonetic environment show a significant difference of $23 \% .^{24}$

23 Data for chart a) in Table 8: s $>0 / \ldots$ C $19=1 . \mathrm{s}>0 / \ldots$ C $11+2 . \mathrm{s}>0 / \ldots \# \mid \mathrm{C} 5+3 . \mathrm{s}>0 / \ldots \mathrm{S} 1+4$.

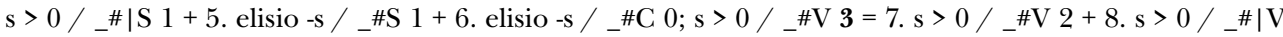
1; excluded items with undeterminable phonetic environment: $2=9 . \mathrm{s}>0 /$ \#hV $0+10 . \mathrm{s}>0 / \ldots \# \mid \mathrm{hV} 0$ + 11. $-\mathrm{s}>0 /$ _ \# || 2 .

24 Data for chart a) in Table 9: s > /_ \#C 18=1. s>0/_\#C 10+2. s>0/_\#|C 5+3. s $>0 / \ldots$ _ $3+4$.

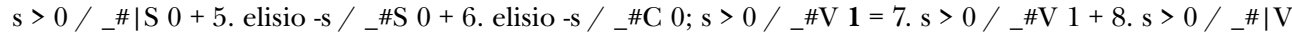




\section{Table 10: Frequency of $-\mathrm{s}>0$ and $-\mathrm{s}=\mathrm{S}$ in phonetic context, Southern Italy c. 4-7 AD}

Frequency of $s>0 / \# V \& s>0 /$ \#C in Southern Italy Frequency of $s=s /$ \#V \& $s=s /$ \#C in Southern Italy Reg. I-VII (LLDB, 301-700 AD, N = 19)

Reg. I-VII (EDCS, 1888 christ. inscr. of ca. 301-700 AD)

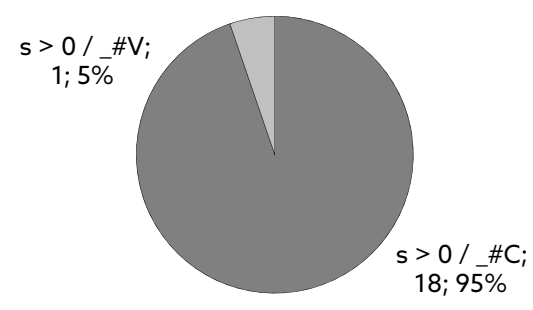

a) omission of -s

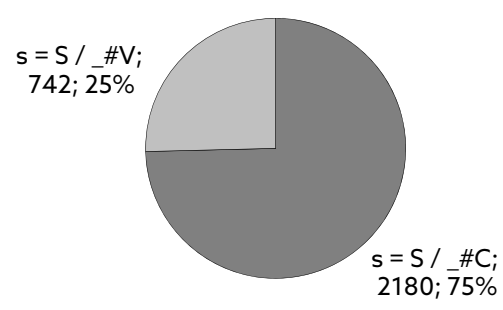

b) retention of -s

At the same time, the rates of both the omission of the final $-s(95 \%)$ and the retention of the final $-s(75 \%)$ in Middle and Southern Italy (Reg. I-VII) compared by phonetic environment in the Later Empire show a similar difference of a significant $20 \% .{ }^{25}$ This means that the difference is again the double of the general level of the Later Empire in both considered regions of Italy (exactly the double in the latter with $10 \%$ and even more than double in the former with $23 \%$ ) if compared with the $10 \%$ difference on the general level of the Later Empire (see Table 6).

8. If we compare the rates of differences between the loss and retention of $-s$ before subsequent consonants recorded for both considered regions of Italy with those recorded for the Republican age based on CIL 1 containing mainly material from Italy, we can draw the following conclusions. In the Republican age the contrastive (14\%) difference between the loss of $-s(90 \%)$ and the retention of $-s(76 \%)$ before subsequent consonants (Table 4) evidences the prevalence of the consonantal environment in the omission of word final $-s$, which reveals that word final $-s$ was liable to vanish in pronunciation before a consonant. This situation is reflected in early Latin verse, where the final $-s$ often does not make position before a consonant while it does before a vowel. Due to the standardisation process ${ }^{26}$ started in the late Republic by restoring word-final consonants both in writing and educated pronunciation, the difference between the loss of $-s(79 \%)$ and the retention of $-s(73 \%)$ before subsequent consonants decreased to $6 \%$ on the general level in the Early Empire (Table 5). In upper and lower Italy (outside of Rome) this difference, however, decreased only to $12 \%$ (Table 7 ) and $11 \%$ (Table 8 ) respectively. During the Later Empire in general the difference between the loss of $-s(81 \%)$ and retention of -s $(71 \%)$ before subsequent consonants again increased to $10 \%$, while in upper and lower

0 ; excluded items with undeterminable phonetic environment: $1=9 . \mathrm{s}>0 / \_\# \mathrm{hV} 0+10 . \mathrm{s}>0 / \_\# \mid \mathrm{hV}$ $0+11 .-\mathrm{s}>0 /$ _ \# || 1 .

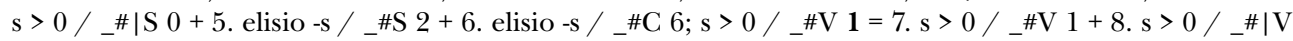
0 ; excluded items with undeterminable phonetic environment: $\overline{7}=9 . \mathrm{s}>0 / \ldots \# \mathrm{hV} 0+10 . \mathrm{s}>0 / \ldots$ $0+11 .-\mathrm{s}>0 /{ }_{-} \#|| 7$. 
Italy (outside of Rome) this difference increased even more, to 23\% (Table 9) and 20\% (Table 10) respectively.

All the above supports our assumption about the increasing importance of the phonetic, i.e. consonantal environment in the loss of final $-s$ generally in the later period. However, it also refutes our second assumption that the later history of the final $-s$ in early Romance with the well-known distinction of loss of final $-s$ in Eastern Romance and retention of final $-s$ in Western Romance (according to linguistic geography divided by the so called Massa-Senigallia line in Northern Italy) ${ }^{27}$ might have been connected to this later tendency of the more and more frequent omission of the final $-s$ before a subsequent consonant, at least directly. In this respect, later Middle and Southern Italy with a $20 \%$ difference in favour of the loss of $-s$ over the retention of $-s$, and later Northern Italy with a $23 \%$ difference in favour of the loss of $-s$ over the retention of $-s$ do not differ significantly from each other (by $3 \%$ i.e. within the error margin of about $4-5 \%$ ).

The obvious increase in the loss of word final $-s$ as attested in relation to the early period by $4 \%(6 \%>10 \%)$ on the general level and by $11 \%(12 \%>23 \%)$ in upper Italy and $9 \%(11 \%>20 \%)$ in lower Italy seems not connected to the merger of the nominative and accusative cases remaining on the same $2 \%$ rate on the general level in both periods but decreasing from the early 3\% (1 item) to the later 1\% (2 items) in Northern Italy and slightly increasing from the early $2 \%$ (2 items) to the later $5 \%$ ( 3 items) in Middle and Southern Italy. Apart from these findings, general indications also suggest that there was no connection between the loss of word final $-s$ and the merger of the nominative and accusative cases, since, as Herman (1997: p. 24) pointed out, the merger of the nominative and accusative cases occurred not only in regions where word final $-s$ was lost like in Eastern Romance, but also in those regions where word final $-s$ was retained as e.g. in Ibero-Romance.

These findings let us deduce that the loss of final $-s$ in Eastern Romance might have happened after the $7^{\text {th }}$ century A.D. either in the phase of transition from Latin to Romance or even in early Romance. This loss might be explained by radical morphological innovations in Eastern Romance, such as the analogical replacement of the thirddeclension nominative plural ending -es with - $i$ (like Rumanian munți and Italian monti from monti, but Spanish and Portuguese montes from montes etc. $)^{28}$ that might have radically decreased the general frequency of final $-s$ and increased the phonosyntactically determined liability for deleting final $-s$ in the early Eastern Romance languages: here the end result was its complete loss. Conversely, in Western Romance languages similar morphological innovations did not reduce but increased the general frequency of final $-s$ e.g. by the generalization of the ending - as as first-declension nominative plural ending (like French chèvres, Spanish and Portuguese cabras from capras, but Rumanian and Italian capre etc.), and this way the phonosyntactically determined liability for deleting final -s could not be fully realised: here the final result was the complete retention.

27 According to Rohlfs (1949: p. 308), the final $-s$ was lost in the northern dialects of Italian only in the middle ages leaving its traces in various dialects until now (cf. Zamboni 1967-1968: p. 118, note 144).

28 As for the problematic origins of the nominal plural endings of Italian, see Herman (1997), Zamboni (2000: pp. 189-197), and Faraoni (2014). 
To sum up, although the whole problem cannot obviously be solved here, the following provisional conclusion seems to be valid. The phonosyntactically determined deletion of final $-s$ before subsequent consonants must have continuously existed all along the history of Latin and could not be suppressed irrevocably by any standardisation process. This situation might have been inherited by the Romance languages where different and complex morphological innovations led either to the discontinuation of the phenomenon of phonosyntactically determined deletion and the stabilization of word final $-s$ (as in Western Romance), or to the completion of the deletion process and the complete loss of final $-s$ (as in Eastern Romance).

\section{Bibliography}

Adamik, B. (2014a). Zur Prosodie, Metrik und Interpretation von Catulls Carmen 116. Wiener Studien, 127, 151-164.

Adamik, B. (2014b). In Search of the Regional Diversification of Latin: Changes of the Declension System According to the Inscriptions. In P. Molinelli, P. Cuzzolin, \& P. Fedriani (Eds.), Latin Vulgaire - Latin Tardif X: Actes du $X^{e}$ colloque international sur le latin vulgaire et tardif, Bergamo, 5-9 septembre 2012 (Tome 2; pp. 641-661). Bergamo: Universita degli Studi di Bergamo.

Adamik, B. (2015). The Periodization of Latin: an Old Question Revisited. In G. Haverling (Ed.), Latin Linguistics in the Early $21^{\text {st }}$ Century: Acts of the $16^{\text {th }}$ International Colloquium on Latin Linguistics, Uppsala, June $6^{\text {th }}-11^{\text {th }}$, 2011 (pp. 640-652). Uppsala: Uppsala Universitet.

Adams, J. N. (2013). Social variation and the Latin language. Cambridge: Cambridge University Press.

Audollent, A. (1904). Defixionum tabellae quotquot innotuerunt tam in Graecis Orientis quam in totius Occidentis partibus. Luteciae Parisiorum: In aedibus Alberti Fontemoing.

EDCS = M. Clauss, A. Kolb, \& W. A. Slaby, Epigraphik-Datenbank Clauss / Slaby (retrieved 22.09.2017 from http://db.edcs.eu/epigr/).

Edmondson, J. (2015). Inscribing Roman Texts: Officinae, Layout, and Carving Techniques. In Ch. Bruun, \& J. Edmondson (Eds.), The Oxford Handbook of Roman Epigraphy (pp. 111-130). Oxford: Oxford University Press.

Faraoni, V. (2014). La formazione del plurale italo-romanzo nella documentazione notarile altomedievale. In P. Molinelli, P. Cuzzolin, \& P. Fedriani (Eds.), Latin Vulgaire - Latin Tardif X: Actes $d u X^{e}$ colloque international sur le latin vulgaire et tardif, Bergamo, 5-9 septembre 2012 (Tome 1; pp. 99-117). Bergamo: Universita degli Studi di Bergamo.

Herman, J. (1987=2006). La disparition de $-s$ et la morphologie dialectale du latin parlé. In J. Herman, Du latin aux langues Romanes II. Nouvelles études de linguistique historique (réun. S. Kiss; pp. 33-42). Tübingen: Niemeyer.

Herman, J. (1997). À propos du débat sur le pluriel des noms italiens (et roumains): à la recherce d'une conclusion. In G. Holtus, J. Kramer, \& W. Schweickard (Eds.), Italica et Romanica. Festschrift für Max Pfister zum 65. Geburtstag (pp. 19-30). Tübingen: Niemeyer.

Herman, J. (2000). Vulgar Latin (transl. R. Wright). University Park, Pa: The Pennsylvania State University Press. 
Hofmann, J. B., \& Szantyr A. (1972²). Lateinische Syntax und Stilistik. München: C. H. Beck'sche Verlagsbuchhandlung.

Kropp, A. (2008). Defixiones. Ein aktuelles Corpus lateinischer Fluchtafeln. Speyer: KartoffeldruckVerlag.

LLDB = B. Adamik et al., Computerized Historical Linguistic Database of Latin Inscriptions of the Imperial Age (retrieved 22.09.2017 from http://lldb.elte.hu/).

Lupinu, G. (2000). Latino epigrafico della Sardegna. Aspetti fonetici. Nuoro: Ilisso Edizioni.

Proskauer, C. (1910). Das auslautende -s auf den lateinischen Inschriften. Straßburg: Verlag von Karl J. Trübner.

Renzi, L., \& Salvi, G. (1985). Nuova introduzione alla filologia romanza. Bologna: Il Mulino.

REW = Meyer-Lübke, W. $\left(1935^{2}\right)$. Romanisches etymologisches Wörterbuch. Heidelberg: Carl Winters Universitätsbuchhandlung.

Rohlfs, G. (1949). Historische Grammatik der italienischen Sprache und ihrer Mundarten, 1: Lautlehre. Bern: Francke Verlag.

Svennung, J. (1935). Untersuchungen zu Palladius und zur lateinischen Fach- und Volkssprache. Lund: Almqvist och Wiksells boktryckeri.

Väänänen, V. (1966). Le latin vulgaire des inscriptions pompéiennes. Berlin: Akademie-Verlag.

Wachter, R. (1987). Altlateinische Inschriften. Sprachliche und epigraphische Untersuchungen zu den Dokumenten bis etwa 150 v. Chr. Bern - Frankfurt am Main - New York - Paris: Peter Lang.

Zamboni, A. (1967-1968). Contributo allo studio del latino epigrafico della X Regio Augustea (Venetia et Histria). Fonetica (vocali in iato e consonantismo). Atti dell'Istituto veneto di scienze, lettere ed arti, 126, 77-129.

Zamboni, A. (2000). Alle origini dell'italiano. Dinamiche e tiplogie della transizione dal latino. Roma: Carocci.

Dr. habil. Béla Adamik PhD / adamik.bela@nytud.mta.hu

Lendület ('Momentum') Research Group for Computational Latin Dialectology

Research Institute for Linguistics of the Hungarian Academy of Sciences

Benczúr u. 33, 1068 Budapest, Hungary 
